\title{
Sequential Determination of Benserazide and Levodopa by Voltammetric Method using Chloranil as a Mediator
}

\author{
Ali A. Ensafi,* A. Arabzadeh and H. Karimi-Maleh \\ Department of Chemistry, Isfahan University of Technology, Isfahan 84156-83111, Iran
}

\begin{abstract}
Descrevemos um método eletroquímico para a determinação voltamétrica seqüencial de benserazida e levodopa usando cloroanil (CA) como eletro-catalisador. Para investigar a adequação do CA como mediador na oxidação eletrocatalitica da benserazida e levodopa, em solução aquosa, foram usadas a voltametria cíclica, voltametria de pulso diferencial, cronoamperometria e espectroscopia de impedância eletroquímica (EIE). A oxidação da levodopa e da benserazida ocorrem, respectivamente, em potenciais aproximadamente $230 \mathrm{e} 480 \mathrm{mV}$ menos positivos do que com o eletrodo de pasta de carbono não modificado usado. Sob condições ótimas, a corrente de pico da oxidação eletrocatalítica da levodopa e benserazida mostraram dois intervalos dinâmicos lineares com limite de detecção de $0,65 \mu \mathrm{mol} \mathrm{L} \mathrm{L}^{-1}$ e $0,95 \mu \mathrm{mol} \mathrm{L} \mathrm{L}^{-1}$, respectivamente. $\mathrm{O}$ desvio padrão relativo para a determinação de $5,0 \times 10^{-5} \mathrm{~mol} \mathrm{~L}^{-1}$ de benserazida e $5,0 \times 10^{-4} \mathrm{~mol} \mathrm{~L}^{-1}$ de levodopa foram 2,0 e 2,0\% $(n=5)$, respectivamente. Os intervalos de calibração lineares foram

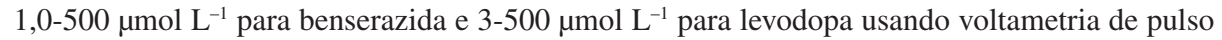
diferencial. O método proposto foi testado com sucesso na determinação da levodopa e benserazida em amostras de urina, demonstrando boa aplicabilidade e confiabilidade.
\end{abstract}

An electrochemical method is described for the sequential voltammetric determination of benserazide and levodopa using chloranil (CA) as an electrocatalyst. Cyclic voltammetry, differential pulse voltammetry, chronoamperometry, and electrochemical impedance spectroscopy (EIS) were used to investigate the suitability of CA as a mediator for the electrocatalytic oxidation of benserazide and levodopa in an aqueous solution. The oxidation peak potential of levodopa and benserazide shifted at about 230 and $480 \mathrm{mV}$ to a less positive potential, respectively, than with the unmodified carbon paste electrode. Under optimum conditions, the electrocatalytic oxidation peak current of levodopa and benserazide showed two linear dynamic ranges with limit of detection of $0.65 \mu \mathrm{mol} \mathrm{L}^{-1}$ and $0.95 \mu \mathrm{mol} \mathrm{L}^{-1}$, respectively. The relative standard deviations for the determination of $5.0 \times 10^{-5} \mathrm{~mol} \mathrm{~L}^{-1}$ benserazide and $5.0 \times 10^{-4} \mathrm{~mol} \mathrm{~L}^{-1}$ levodopa were 2.0 and $2.0 \%(\mathrm{n}=5)$, respectively. The linear calibration ranges were $1.0-500 \mu \mathrm{mol} \mathrm{L}{ }^{-1}$ for benserazide

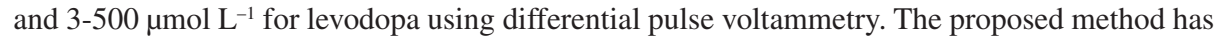
been successfully applied for the determination of levodopa and benserazide in urine samples, demonstrating the feasibility and reliability of the proposed method.

Keywords: levodopa and benserazide, sequential determination, cyclic voltammetry, chloranil, electrocatalysis, differential pulse voltammetry

\section{Introduction}

Levodopa (3,4-dihydroxyphenyl-1-alanine) (Scheme 1A), also named L-dopa, is an effective drug for the treatment of Parkinson's disease. However, most administered levodopa is converted into dopamine at periphery, which is caused by aromatic 1-amino acid

*e-mail: ensafi@cc.iut.ac.ir decarboxylase, leaving only a small amount to enter the brain. Therefore, it is usually associated with a peripheral aromatic-1-amino acid decarboxylase inhibitor, such as benserazide $\left[N^{\prime}-(2,3,4-\right.$ trihydroxybenzyl $)-D, L$-serine] (Scheme 1B), in order to increment the proportion that enters the brain. ${ }^{1,2}$

Several methods have been used for the determination of individual levodopa or benserazide in pharmaceutical preparation including spectrophotometry, ${ }^{3}$ 


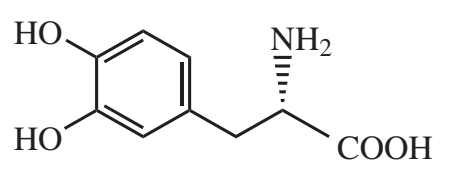

A

Scheme 1. A) Structure of levodopa; B) Structure of benserazide.

chemiluminescence, ${ }^{4}$ electrochemistry, ${ }^{5,6}$ and liquid chromatography. ${ }^{7-10}$ Increasing attention has been recently drawn to the sequential and/or simultaneous determination of benserazide and levodopa including capillary electrophoresis ${ }^{11-14}$ with spectrophotometric, electrochemical and chemiluminescence detections. ${ }^{15-17}$

Amperometric and voltammetric detections have been widely used as inexpensive and sensitive techniques for detecting electroactive compounds in pharmaceutical formulations, biological matrices and medicinal herbs. Voltammetric detection is a promising means of determining electroactive impurities in pharmaceutical formulations. Because both levodopa and benserazide contain hydroxyl groups on their aromatic rings, both analytes are electroactive, which makes them suitable for electrochemical detection.

The aim of this work was to develop an efficient method for rapid analysis of levodopa and benserazide using voltammetric method. As far as we know, electrocatalytic determination of benserazide using modified electrodes has not been reported in the literature. Therefore, we studied the application of chloranil (CA) as a suitable mediator for the determination of levodopa and benserazide in aqueous media using cyclic and differential pulse voltammetry (DPV). In addition, the suitability of CA modified carbon paste electrode (CAMCPE) in the electrocatalysis and determination of levodopa and benserazide is investigated by cyclic voltammetry (CV), electrochemical impedance spectroscopy (EIS), and chronoamperometry.

\section{Experimental}

\section{Reagents}

All chemicals were of analytical grade purchased from Merck (Darmstadt, Germany) and Sigma-Aldrich unless otherwise stated. Doubly distilled water was used throughout.

The $1.0 \times 10^{-2} \mathrm{~mol} \mathrm{~L}^{-1}$ benserazide and levodopa solutions were prepared daily by dissolving $0.0147 \mathrm{~g}$ benserazide and $0.0099 \mathrm{~g}$ levodopa in water, diluting the solution to $5 \mathrm{~mL}$ with water in a $5 \mathrm{~mL}$ volumetric flask. This<smiles>N[C@@H](CO)C(=O)NNCc1ccc(O)c(O)c1O</smiles>

B

solution is stable for, at least, one month. Less concentrated solutions were prepared by serial dilutions with water.

Universal buffer solutions $\left(0.04 \mathrm{~mol} \mathrm{~L}^{-1}\right)$ containing boric acid, phosphoric acid, acetic acid plus sodium hydroxide, with different $\mathrm{pH}$ values were used to study the $\mathrm{pH}$ influence.

Highly viscose paraffin (density $=0.88 \mathrm{~g} \mathrm{~cm}^{-3}$ ) from Fluka (Switzerland) was used as the pasting liquid for preparing the carbon paste electrode. Graphite powder (particle diameter $=0.10 \mathrm{~mm}$ ) from Merck (Darmstadt, Germany) was used as the working electrode (WE).

\section{Apparatus}

Electrochemical measurements were performed with Micro-Autolab, potentiostat/galvanostat instrument connected to a three-electrode cell, Micro-Autolab ( $\mu 3$ AUT-70751) linked to a computer (Pentium IV, $1200 \mathrm{MHz}$ ) and the cell linked to the micro-Autolab software. A conventional threeelectrode cell was used for all experiments. Carbon paste electrode and/or CAMCPE were used as working electrodes, platinum wire as an auxiliary electrode, and a saturated calomel electrode (SCE) as a reference electrode. All potentials were measured versus SCE.

Electrochemical impedance measurements were carried out in a conventional three-electrode cell, powered by an electrochemical system comprising the Autolab system with PGSTAT 12 and FRA2 boards (Eco Chemie B.V., Utrecht, The Netherlands). The system was run on a PC using GPES and FRA 4.9 software. For impedance measurements, a frequency range of $10 \mathrm{kHz}$ to $1 \mathrm{~Hz}$ was employed. The AC voltage amplitude used was $5 \mathrm{mV}$.

A pH-meter (Corning, Model 140) with a double junction glass electrode was used to check the $\mathrm{pH}$ of the solutions.

\section{Preparation of the modified electrode}

A $1.0 \%(\mathrm{~m} / \mathrm{m})$ CA spiked carbon powder was made by dissolving a given quantity of $\mathrm{CA}$ in $\left(\mathrm{C}_{2} \mathrm{H}_{5}\right)_{2} \mathrm{O}$ and by hand mixing with, 99 times its weight, graphite powder with a mortar and pestle. The solvent was evaporated by stirring. 
Paraffin (DC 350, Merck) was added $(0.50 \mathrm{~g}, 0.33 \mathrm{~m} / \mathrm{m})$ to the previous mixture (1.00 $\mathrm{g}$ of the mixture) using a syringe, and the mixture was mixed for 20 min until a uniformly wetted paste was obtained. The paste was then packed into the end of a glass tube (with mean surface area of $0.0434 \mathrm{~cm}^{2}$ ). The electrical connection was implemented with a copper wire fitted into the glass tube. A carbon paste electrode without $\mathrm{CA}$ was prepared according to the above procedure without $\mathrm{CA}$ addition.

\section{Recommended procedure}

The carbon paste electrode was polished with a white and clean paper. To prepare a blank solution, $9.0 \mathrm{~mL}$ of the buffer solution (boric acid, phosphoric acid, acetic acid/ sodium hydroxide, $\mathrm{pH} 10.0)$ and $1.0 \mathrm{~mL} \mathrm{KCl}\left(1.0 \mathrm{~mol} \mathrm{~L}^{-1}\right)$ solution were transferred into a $10 \mathrm{~mL}$ volumetric flask. Then, the solution was transferred to an electrochemical cell. The initial and final potentials were adjusted to $-0.30 \mathrm{~V}$ and $+0.25 \mathrm{~V} v s$. SCE, respectively. DPV (with a modulation time of $0.002 \mathrm{~s}$, an interval time of $0.10 \mathrm{~s}$, a step potential of $1 \mathrm{mV}$, and a modulation amplitude of $50 \mathrm{mV}$ ) was recorded to give the analytical signal $\left(I_{\mathrm{ps}}\right)$ with a scan rate of $10 \mathrm{mV} \mathrm{s}^{-1}$ in the presence of several microliters of levodopa or benserazide solution. The blank signal $\left(I_{\mathrm{pb}}\right)$ was also measured using above solution and procedure without addition of levodopa and benserazide. This net signal $\left(\Delta I_{\mathrm{p}}=I_{\mathrm{ps}}-I_{\mathrm{pb}}\right)$ was proportional to levodopa and benserazide concentrations. Calibration curves were constructed by plotting the sample current $v s$. the levodopa and benserazide concentration. For $\mathrm{CV}$, a scan rate of $50 \mathrm{mV} \mathrm{s}^{-1}$ was used.

\section{Preparation of real samples}

Urine samples were used directly for measurements without any pretreatment but diluted 100 times with the buffer before use. The external standard method was used for the determination of levodopa and benserazide in real samples.

\section{Results and Discussion}

\section{Electrochemistry of the mediator and CAMCPE}

The CAMCPE was constructed by incorporation of chloranil into the carbon paste matrix to study its electrochemical properties in the buffered aqueous solution by cyclic voltammetry. The electrochemical behavior of chloranil into carbon paste matrix was studied by Raoof et al. ${ }^{18}$ The cyclic voltammograms exhibited anodic $\left(\mathrm{E}_{\mathrm{pa}}=0.022 \mathrm{~V}\right)$ and the corresponding cathodic peaks
$\left(\mathrm{E}_{\mathrm{pc}}=-0.086 \mathrm{~V}\right) v s$. SCE related to $\mathrm{CA}_{(\mathrm{Red})} / \mathrm{CA}_{(\mathrm{Ox})}$ redox couple with quasi-reversible behavior. ${ }^{18}$ In addition, $\mathrm{E}_{1 / 2}$ of $\mathrm{CA}_{(\mathrm{Red})} / \mathrm{CA}_{(\mathrm{Ox})}$ was dependent on the $\mathrm{pH}$ of the solution. The values of $\mathrm{pKa}_{1}$ and $\mathrm{pKa}_{2}$ of the reduced form of chloranil (using cyclic voltammograms data) were equal to 5.82 and 8.00 , respectively. ${ }^{18}$ Since CA is insoluble in aqueous solutions, and it can be used with carbon paste without leaching out from the electrode surface, this leads to a chemically modified electrode that is highly stable. $\mathrm{CA}$ and its reduced form have aromatic ring and $-\mathrm{OH}$ groups, similarly to benserazide and levodopa. Thus, those molecules potentially can interact with them.

To test the electrocatalytic behavior of CA, cyclic voltammograms were recorded at $50 \mathrm{mV} \mathrm{s}^{-1}$ in a universal buffer solution $\left(0.04 \mathrm{~mol} \mathrm{~L}^{-1}, \mathrm{pH} 10.0\right)$ in both the absence and presence of benserazide and/or levodopa, using both an unmodified carbon paste electrode and a CAMCPE. Figures 1 and 2 show that benserazide and levodopa oxidations occur only to a broad extent with highly positive overpotential at the surface of the unmodified carbon paste electrode. With the modified electrode, however, a significant enhancement is achieved in the anodic peak current of benserazide and levodopa at potentials closer to the formal potential of $\mathrm{CA}_{(\mathrm{Red})} / \mathrm{CA}_{(\mathrm{Ox})}$ redox couple along with a decrease in the cathodic current, which suggests that $\mathrm{CA}$ is an effective mediator in the electrocatalytic oxidation of benserazide and/or levodopa. The process corresponds to an EC' (catalytic) mechanism (Scheme 2), where the electrochemically formed $\mathrm{CA}_{(\mathrm{Ox})}$ reacts chemically with benserazide (or levodopa) diffused toward the electrode surface, while the simultaneous oxidation of the regenerated $\mathrm{CA}_{(\text {Red })}$ causes an increase in the anodic current. For the same reason, the cathodic current of the modified electrode is smaller in the presence of benserazide and/or levodopa.

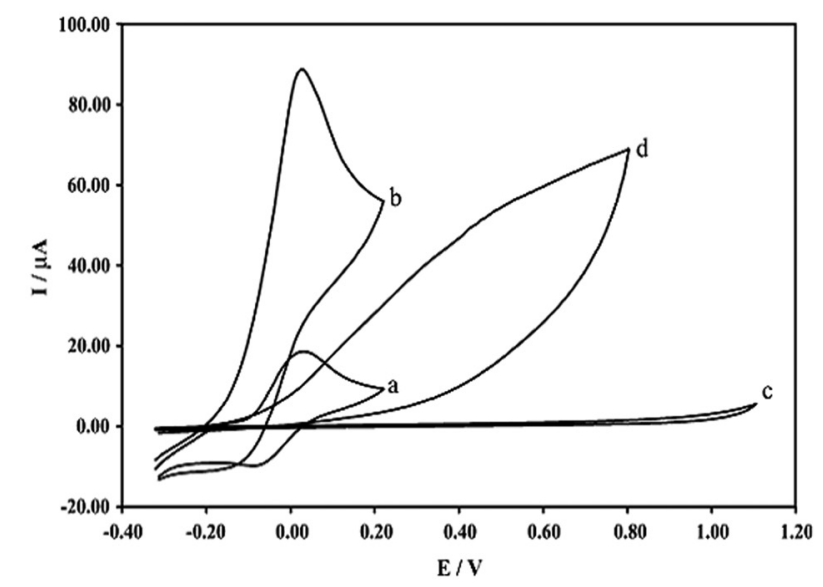

Figure 1. Cyclic voltammograms of CAMCPE in the buffer solution (pH 10.0) and $0.1 \mathrm{~mol} \mathrm{~L}^{-1} \mathrm{KCl}$ : a) In the absence and b) in the presence of $3200 \mu \mathrm{mol} \mathrm{L}^{-1}$ benserazide; (c) as (a) and (d) as b) for an unmodified carbon paste electrode, respectively. 


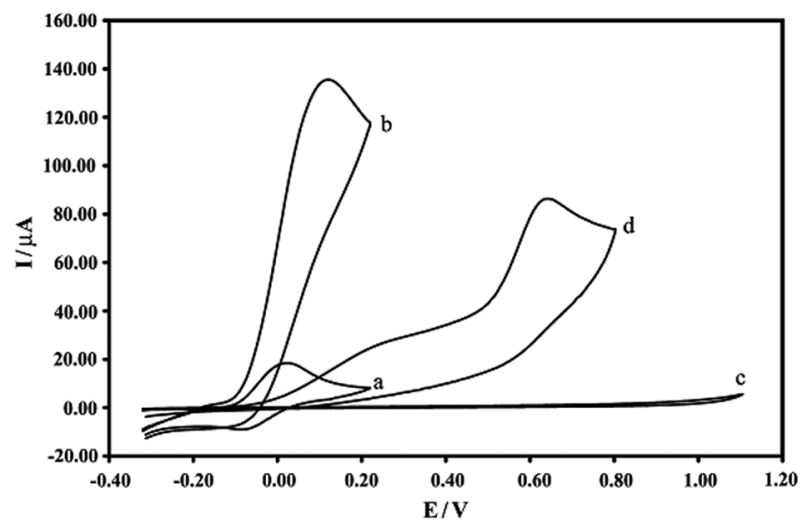

Figure 2. Cyclic voltammograms of CAMCPE in the buffer solution (pH 10.0) and $0.1 \mathrm{~mol} \mathrm{~L}^{-1} \mathrm{KCl}$ at a scan rate of $50 \mathrm{mV} \mathrm{s}^{-1}$ : a) In the absence and b) in the presence of $5000 \mu \mathrm{mol} \mathrm{L} \mathrm{L}^{-1}$ levodopa; (c) as (a) and (d) as (b) for an unmodified carbon paste electrode, respectively.

\section{Influence of variables}

The influence of scan rate on the electrochemical response of $2.0 \times 10^{-4} \mathrm{~mol} \mathrm{~L}^{-1}$ benserazide was also investigated in the range from 10 to $100 \mathrm{mV} \mathrm{s}^{-1}$ the results of which are shown in Figure 3. It can be seen that with increasing scan rate, the redox peak current increases gradually. The relationship between redox peak currents and scan rates was worked out. The results showed that the redox peak currents were proportional to the square root of the scan rate $\left(v^{1 / 2}\right)$ in the range of 10 to $100 \mathrm{mV} \mathrm{s}^{-1}$, which indicated that the electron transfer reaction of benserazide (and/or levodopa) on the CAMCPE was a diffusioncontrolled process in the solution. The electrochemical parameters of the benserazide on the CAMCPE were further calculated.

In order to obtain a better understanding of the rate determining step, Tafel plots were developed for CAMCPE in the presence of benserazide (Figure 4) using the data derived from the raising part of the current-voltage curve at different scan rates (Figure 4, inset $\mathrm{A}$ as an example). The slope of the Tafel plot was equal to $2.3 \mathrm{RT} / \mathrm{n}(1-\alpha) \mathrm{F}$ and equaled $0.0894,0.0897$ and 0.0905 for scan rates of 5,10 and $20 \mathrm{mV} \mathrm{s}^{-1}$, respectively. We could then calculate the mean value of $n(1-\alpha)$ as 0.657 . Because $n=2,{ }^{18}$ then $\alpha=0.671$. In addition, the mean value of $\mathrm{n}(1-\alpha)$ for levodopa was 0.660 , and thus, $\alpha=0.670$.

The rate constant for the chemical reaction between benserazide and redox sites of the CA can be evaluated according to the method of Galus. ${ }^{19}$ In cases where

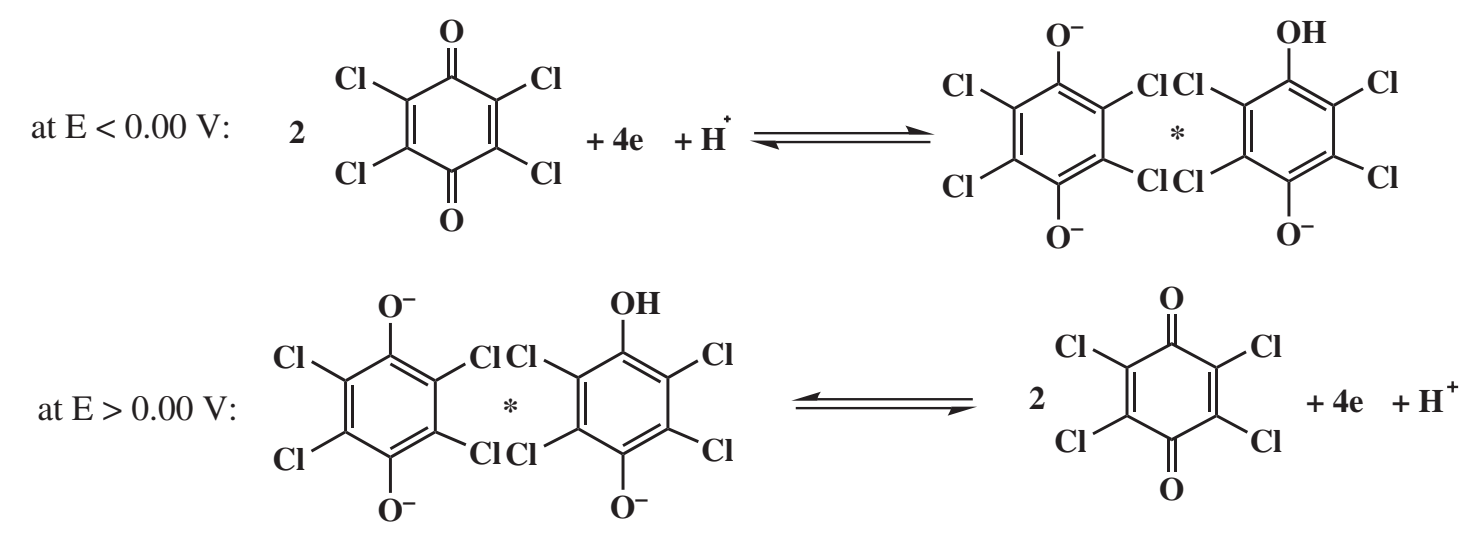<smiles>N[C@@H](CO)C(=O)NNCc1ccc(O)c(O)c1O</smiles><smiles>N[C@@H](Cc1ccc(O)c(O)c1)C(=O)O</smiles><smiles>N[C@@H](CO)C(=O)NNCC1=C(O)C(=O)C(=O)C=C1</smiles>

Scheme 2. Mechanism of the electrocatalytic reaction. 


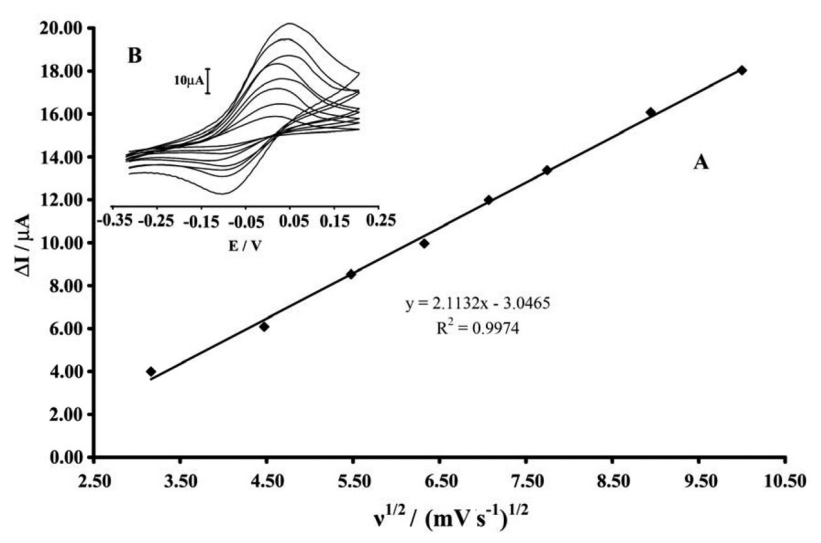

Figure 3. (A) Cyclic voltammograms of $200.0 \mu \mathrm{mol} \mathrm{L} \mathrm{L}^{-1}$ benserazide at various scan rates; a) 10 ; b) 20; c) 30; d) 40; e) 50, f) 60 , g) 80 and g) $100 \mathrm{mV} \mathrm{s}^{-1}$ in $0.04 \mathrm{~mol} \mathrm{~L}^{-1}$ buffer solution (pH 10.0) and $0.1 \mathrm{~mol} \mathrm{~L}^{-1}$ $\mathrm{KCl}$. (B) Plot of $\Delta I$ versus $v^{1 / 2}$ for the oxidation of benserazide at the surface of CAMCPE.

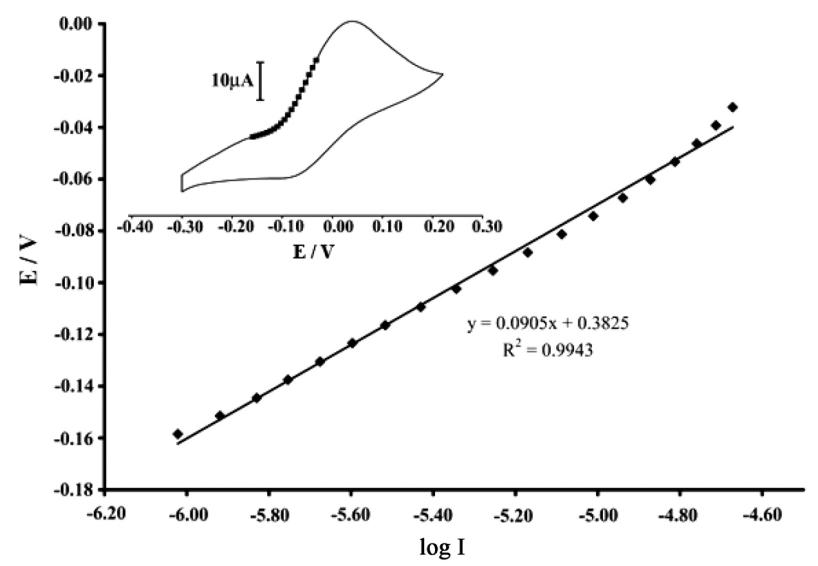

Figure 4. Tafel plot for CAMCPE in buffer solution ( $\mathrm{pH} 10.0$ ) with scan rate of $10 \mathrm{mV} \mathrm{s}^{-1}$ in the presence of $200.0 \mu \mathrm{mol} \mathrm{L}^{-1}$ benserazide.

$\gamma$ exceeds two, the error function is almost equal to one and the equation can be simplified to:

$I_{\mathrm{C}} / I_{\mathrm{L}}=\pi^{1 / 2} \gamma^{1 / 2}=\pi^{1 / 2}\left(\mathrm{k}_{\mathrm{h}} \mathrm{C}_{\mathrm{b}} \mathrm{t}\right)^{1 / 2}$

where, $I_{\mathrm{C}}$ is the catalytic current of CAMCPE in the presence of benserazide, $I_{\mathrm{L}}$ is the limited current in the absence of benserazide, and $\gamma=k_{h} C_{b} t\left(C_{b}\right.$ is the bulk concentration of benserazide, $\left.\mathrm{mol} \mathrm{L}^{-1}\right)$ is the argument of error function. $\mathrm{k}_{\mathrm{h}}$ and $t$ are the catalytic rate constant $\left(\mathrm{mol}^{-1} \mathrm{~L} \mathrm{~s}^{-1}\right)$ and time elapsed (s), respectively. From the slope of $I_{C} I_{\mathrm{L}} v s . \mathrm{t}^{1 / 2}$ plot, the value of $k_{h}$ can be simply calculated for a given concentration of the substrate (Figure 5 as an example). For this study, three different concentrations of benserazide and levodopa were selected, 100, 300 and $1000 \mu \mathrm{mol} \mathrm{L}^{-1}$. The mean values of $\mathrm{k}_{\mathrm{h}}$ are equal to $(5.9 \pm 0.2) \times 10^{3} \mathrm{~mol}^{-1} \mathrm{~L} \mathrm{~s}^{-1}$ and $(3.2 \pm 0.1) \times 10^{3} \mathrm{~mol}^{-1} \mathrm{~L} \mathrm{~s}^{-1}$ for benserazide and levodopa, respectively. This value of $k_{h}$ also explains the sharp feature of the catalytic peak observed for catalytic oxidation of benserazide at the surface of CAMCPE. This method has been used for estimating the value of $k_{h}$ for some compounds..$^{20-23}$

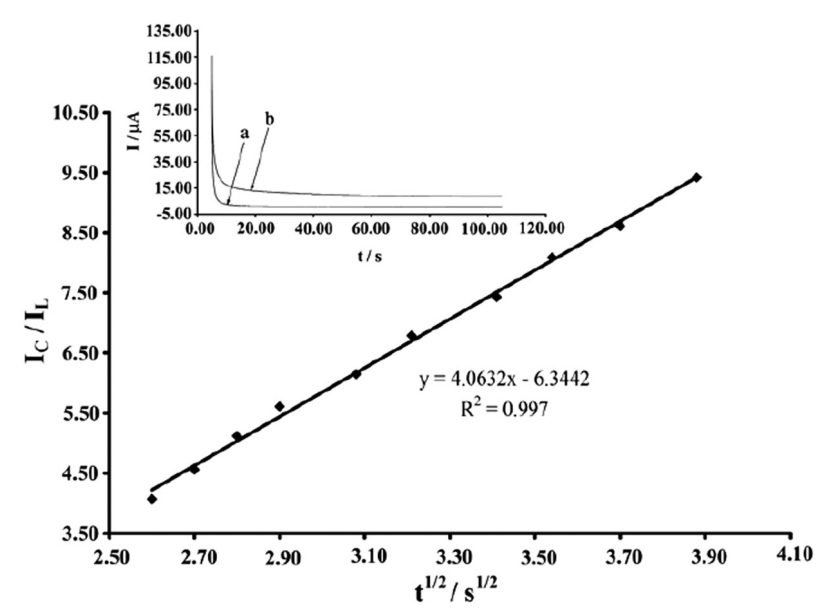

Figure 5. Dependence of $I_{\mathrm{c}} / I_{\mathrm{L}}$ on the $\mathrm{t}_{1 / 2}$ driven from the chronoamperogram data. a) Chronoamperogram for CAMCPE; b) Chronoamperogram for CAMCPE in the presence of $1000 \mu \mathrm{mol} \mathrm{L}-1$ benserazide and $0.1 \mathrm{~mol} \mathrm{~L}^{-1}$ $\mathrm{KCl}$.

The effect of solution $\mathrm{pH}$ on electrochemical responses of benserazide and/or levodopa at the surface of CAMCPE was investigated over a $\mathrm{pH}$ range of 6.5 to 10.5 using cyclic voltammetry. Figure 6 shows the variation in $\Delta I_{\mathrm{pa}}$ versus $\mathrm{pH}$. As observed, in the acidic media, the drugs do not considerably affect the peak current of $\mathrm{CA}$, because the oxidation of CA is difficult to occur under this condition. Furthermore, as stated before, $\mathrm{pKa}_{2}$ of the reduced form of CA is about $8.00 .{ }^{18}$ The suitable form of the reduced form of $\mathrm{CA}$, that undergoes oxidation on the paste electrode is the anionic form (Scheme 2). Thus, oxidation of the reduced

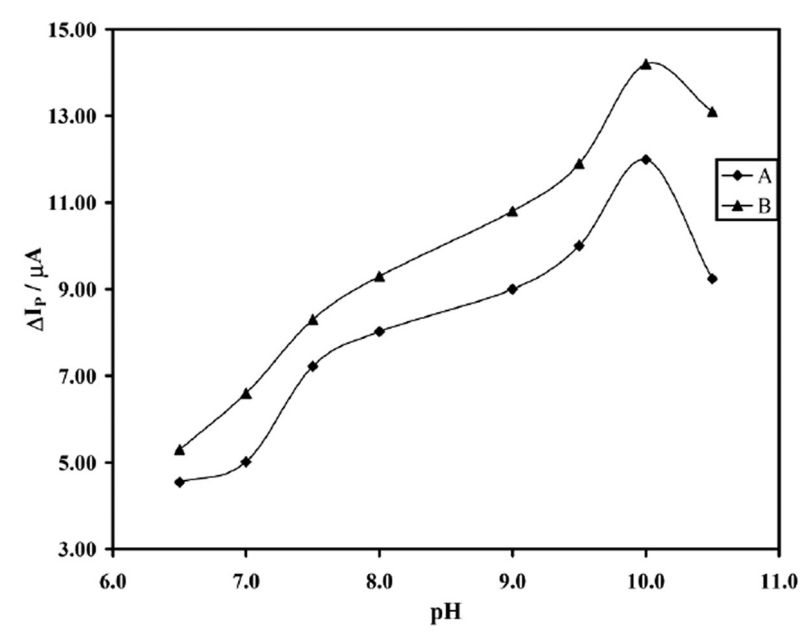

Figure 6. Current-pH curves for electro-oxidation of $200.0 \mu \mathrm{mol} \mathrm{L} \mathrm{L}^{-1}$ benserazide (A) and levodopa (B) in buffer solution with different $\mathrm{pH}$ values at the surface of CAMCPE and $0.1 \mathrm{~mol} \mathrm{~L}^{-1} \mathrm{KCl}$, with $50 \mathrm{mV} \mathrm{s}^{-1}$ scan rate. 
form to the oxidized form of CA is easier in basic media. Therefore, we observed a better electrocatalytic behavior for $\mathrm{CA}$ in the basic solution. When the $\mathrm{pH}$ level was increased to above 10.5, no enhancement was observed in the peak current due to changes in drugs' structures. As can be seen, maximum electrocatalytic current was obtained at $\mathrm{pH}$ 10.0. Therefore, $\mathrm{pH} 10.0$ was chosen as the optimum $\mathrm{pH}$ for the electrocatalysis of benserazide oxidation at the surface of CAMCPE. Moreover, benserazide and levodopa could be oxidized at a slow rate in basic media $(\mathrm{pH}>9)$ in the presence of oxygen, when the solution was stirred. Our studies showed that only about $5 \%$ of $2.0 \times 10^{-4} \mathrm{~mol} \mathrm{~L}^{-1}$ benserazide and/or levodopa were oxidized at $\mathrm{pH} 10.0$ in the first $30 \mathrm{~min}$ of the mixing. As such, the sample solution did not need degassing with $\mathrm{N}_{2}$ before the experiment.

\section{Electrochemical impedance spectroscopy studies}

Electrochemical impedance spectroscopy was also employed to investigate the oxidation of benserazide on the CAMCPE. Figure 7 represents Nyquist diagrams of the imaginary impedance $\left(Z_{i m}\right)$ versus the real impedance $\left(\mathrm{Z}_{\mathrm{re}}\right)$ of the EIS obtained at the modified electrode in the absence (curve a) and presence of $200 \mu \mathrm{mol} \mathrm{L}^{-1}$ benserazide (curve b) in $0.04 \mathrm{~mol} \mathrm{~L}^{-1}$ universal buffer, $\mathrm{pH}$ 10.0. In the absence of benserazide, the Nyquist diagram comprises a depressed semicircle at high frequencies, which can be related to the combination of charge transfer resistance of CA electrooxidation and the double-layer capacitance, followed by a straight line with a slope of nearly $45^{\circ}$. The latter is due to the occurrence of mass transport process via diffusion.

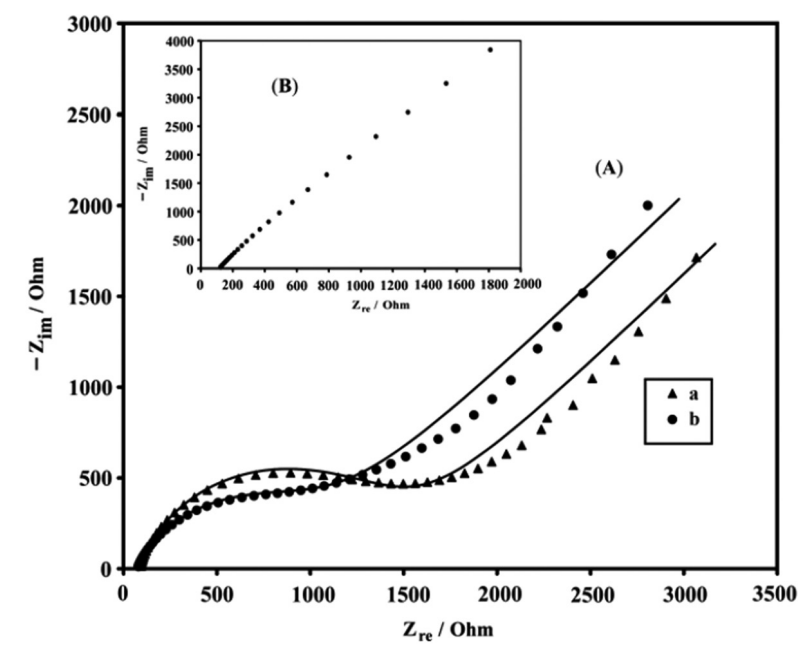

Figure 7. Nyquist diagrams; A) CAMCPE in the a) absence, and b) presence of $200 \mu \mathrm{mol} \mathrm{L}{ }^{-1}$ benserazide at $\mathrm{pH} 10.0$ and $0.1 \mathrm{~mol} \mathrm{~L}^{-1} \mathrm{KCl}$. Bias is $-0.035 \mathrm{~V}$ with Eac $=5 \mathrm{mV}$ and frequency range of $10 \mathrm{kHz}$ to $1 \mathrm{~Hz}$. Inset B) shows Nyquist diagrams of $200 \mu \mathrm{mol} \mathrm{L}^{-1}$ benserazide with the unmodified CPE. Points (a and c) show the experimental data and the full line is calculated from the optimized parameters.
The equivalent circuit compatible with the Nyquist diagram recorded in the absence and presence of benserazide is depicted in Scheme 3. In this circuit, $R_{\mathrm{s}}$, $\mathrm{CPE}_{\mathrm{dl}}$, and $\mathrm{R}_{\mathrm{ct}}$ represent solution resistance, a constant phase element corresponding to the double-layer capacitance and the charge transfer resistance. $\mathrm{W}$ is a finite-length Warburg short-circuit term coupled to $\mathrm{R}_{\mathrm{ct}}$, which accounts for the Nernstian diffusion. In the presence of benserazide, the diameter of the semicircle decreases, confirming the electrocatalytic capability of the mentioned electrocatalyst for oxidation of benserazide. This is due to the instant chemical reaction of benserazide with the $\mathrm{CA}_{\text {(ox) }}$ species. The catalytic reaction of benserazide oxidation causes an increase in the surface concentration of $\mathrm{CA}_{(\mathrm{Red})}$, and the charge transfer resistance becomes low, depending on the concentration of benserazide in the solution. This behavior is consistent with the results of cyclic voltammetry and chronoamperometry (see Figure 2 and Scheme 3). Impedance of CPE and W elements can be expressed as: $:^{24}$

$Z_{C P E}=\left(Y_{0} j \omega\right)^{-n}$

$Z W=Y_{0}^{-1}(j \omega)^{-1 / 2}$

where, $\mathrm{Y}_{0}$ (the admittance parameter, $\mathrm{S} \mathrm{cm}^{-2} \mathrm{~s}^{-\mathrm{n}}$ ) and $\mathrm{n}$ (dimensionless exponent) are two parameters independent of frequency; $j=(-1)^{1 / 2}$ and $\omega=$ angular frequency $=2 \pi f$. $\mathrm{CPE}$ corresponds to the constant phase angle element impedance. $\mathrm{Y}_{0}=\mathrm{C}_{\mathrm{dl}}$ only when $\mathrm{n}=1$, and $\mathrm{n}$ is related to $\alpha$ (phase angle) by $\alpha=(1-n) 90^{\circ}$. So, $\mathrm{n}=1$ and $\alpha=0$ stand for a perfect capacitor, and the lower $n$ values directly reflect the roughness of the electrode surface. When $\mathrm{n}=0.5$, it is equal to a Warburg impedance. When $\mathrm{n}=0$, CPE is reduced to a resistor. Table 1 lists the values of the equivalent circuit elements obtained by fitting the

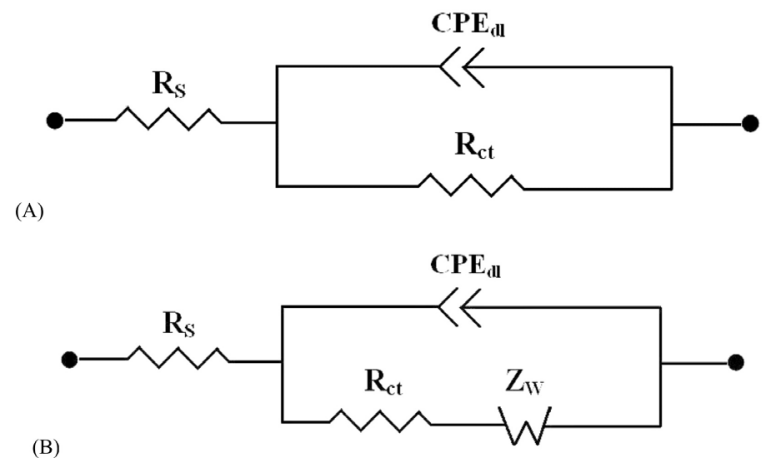

Scheme 3. The equivalent circuit compatible with the Nyquist diagram recorded in Figure 7; A) For $200.0 \mu \mathrm{mol} \mathrm{L} \mathrm{L}^{-1}$ benserazide with the unmodified $\mathrm{CPE}$, and $\mathrm{B}$ ) with the absence and presence of benserazide using the MCPE. 
Table 1. Values of the equivalent circuit elements obtained by fitting the experimental results for the electrocatalyst in the absence and presence of benserazide for Nyquist plots represented in Figure 7 and the corresponding relative errors

\begin{tabular}{|c|c|c|c|c|c|c|}
\hline \multirow{2}{*}{ Electrode } & \multirow{2}{*}{$\begin{array}{c}\text { Benserazide } \\
\left.(\mu \mathrm{mol} \mathrm{L})^{-1}\right)\end{array}$} & \multirow{2}{*}{$\begin{array}{c}\mathrm{R}_{\mathrm{s}} \\
(\mathrm{Ohms})\end{array}$} & \multicolumn{2}{|c|}{ CPE } & \multirow{2}{*}{$\begin{array}{c}\mathrm{Z}_{\mathrm{W}} \times 10^{3} \\
(\mathrm{Ohms})\end{array}$} & \multirow{2}{*}{$\begin{array}{c}\mathrm{R}_{\mathrm{ct}} \\
(\mathrm{Ohms})\end{array}$} \\
\hline & & & $\mathrm{Y}_{0} \times 10^{5}\left(\mathrm{~S} \mathrm{~cm}^{-2} \mathrm{~s}^{-n}\right)$ & $\mathrm{n}$ & & \\
\hline MCPE & - & $87.40(1.39 \%)$ & $0.2223(6.86 \%)$ & $0.8097(0.94 \%)$ & $0.249(1.63 \%)$ & $1366(1.61 \%)$ \\
\hline MCPE & 200 & $73.20(1.60 \%)$ & $0.5828(8.73 \%)$ & $0.7508(1.31 \%)$ & $0.2167 \mathrm{n}(1.57 \%)$ & $1016(2.74 \%)$ \\
\hline
\end{tabular}

experimental results for the electrocatalyst, in the absence and presence of benserazide. The goodness of fit can be judged by the estimated relative errors presented in parentheses.

In the mentioned circuits, the charge-transfer resistance of the electrode reaction is the only circuit element that has a simple physical meaning describing how fast the rate of charge transfer during electro-oxidation of benserazide changes with the electrode potential. To obtain a satisfactory fitting of Nyquist diagrams, it was necessary to replace the double-layer capacitance with a constant phase element in the equivalent circuit. The most widely accepted explanation for the presence of constant phase elements and the appearance of depressed semicircles in Nyquist plots is microscopic roughness, causing an inhomogeneous distribution in the solution resistance as well as in the double-layer capacitance. ${ }^{25}$

\section{Analytical parameters}

The rate loss of electrochemical activity of CAMCPE was investigated using $\mathrm{CV}$ in consecutive potential scan cycles. The results showed that the anodic and cathodic peak currents of the reduced and oxidized form of CA decreased. This means that the electrochemical activity of CAMCPE is reduced during successive scans. The decrease in the electrochemical activity is due to removal of the mediator from the electrode by dissolution into aqueous solution. Thus, it is necessary to renew the electrode surface before each determination by polishing the electrode surface using a white and clean paper. However, determination was done with $10 \mathrm{~s}$ equilibrium time, whereas immersion time of the carbon paste electrode on the electrolytic solution did not show any influence on the current response.

Differential pulse voltammetric method was used for the determination of benserazide and levodopa (Figures 8 and 9) due to its greater sensitivity compared to CV. The results showed that benserazide has two linear dynamic ranges, from $1.0-20 \mu \mathrm{mol} \mathrm{L} \mathrm{L}^{-1}$ with a regression equation of $\Delta I_{\mathrm{p}}(\mu \mathrm{A})=(0.125 \pm 0.008) \mathrm{C}_{\text {benserazide }}+0.072 \pm 0.009$ $\left(\mathrm{R}^{2}=0.9928, \mathrm{n}=5\right)$ and from $20-500 \mu \mathrm{mol} \mathrm{L} \mathrm{L}^{-1}$ with a regression equation of $\Delta I_{\mathrm{p}}(\mu \mathrm{A})=(0.0311 \pm 0.009)$

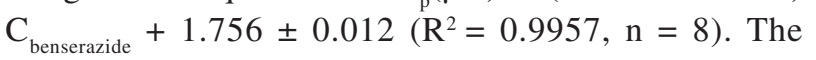

calibration curve of levodopa also showed two linear

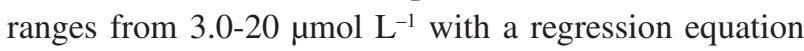
of $\Delta I_{\mathrm{p}}(\mu \mathrm{A})=(0.167 \pm 0.010) \mathrm{C}_{\text {levodopa }}-0.134 \pm 0.007$ $\left(\mathrm{R}^{2}=0.997, \mathrm{n}=4\right)$ and for $20-500 \mu \mathrm{mol} \mathrm{L} \mathrm{L}^{-1}$ with a regression equation of $\Delta I_{\mathrm{p}}(\mu \mathrm{A})=(0.0313 \pm 0.007) \mathrm{C}_{\text {levodopa }}+$ $1.512 \pm 0.020\left(\mathrm{R}^{2}=0.9947, \mathrm{n}=7\right)$, where $\Delta I_{\mathrm{p}}$ is the net peak current $\left(\Delta I_{\mathrm{p}}=I_{\mathrm{ps}}-I_{\mathrm{pb}}\right)$ and $\mathrm{C}$ is the concentration of the analyte $v s . \mu \mathrm{mol} \mathrm{L} \mathrm{L}^{-1}$.

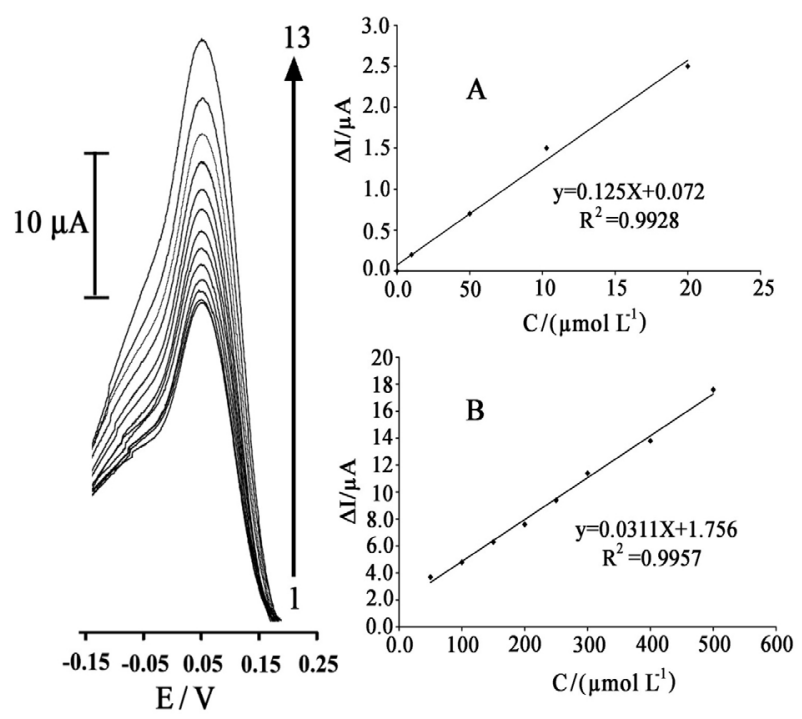

Figure 8. Diffrential pulse voltammograms of benserazide at various concentration: 1) 0.0 , 2) $1.0,3) 5$, 4) 10 , 5) 20, 6) 50 , 7) 100,8$) 150,9) 200,10) 250,11) 300,12) 400$, and 13) 500 $\mu \mathrm{mol} \mathrm{L}{ }^{-1}$ benserazide at the surface of CAMCPE. Conditions: $\mathrm{pH} 10.0$; $\mathrm{KCl} 0.1 \mathrm{~mol} \mathrm{~L}^{-1}$; Scan rate $10 \mathrm{mV} \mathrm{s}^{-1}$; Inset A) and B) are plots of the electrocatalytic net peaks current $v s$. benserazide concentrations.

The limits of detection, defined as three times the blank standard deviation signal, were 0.65 and $0.95 \mu \mathrm{mol} \mathrm{L} \mathrm{L}^{-1}$ for benserazide and levodopa, respectively.

To investigate the precision of the proposed method, the CAMCPE was used for the determination of $50.0(\mathrm{n}=8) \mu \mathrm{mol} \mathrm{L}{ }^{-1}$ benserazide and $500(\mathrm{n}=5) \mu \mathrm{mol} \mathrm{L}{ }^{-1}$ levodopa. The relative standard deviation ( $\mathrm{RSD} \%$ ) for each case was calculated and determined as 2.0 and $2.0 \%$, respectively. The stability of CAMCPE was also studied. After the CAMCPE had been stored for 2 weeks, no apparent decrease was observed in its electrochemical response to benserazide, which indicated the good stability of the CAMCPE. 


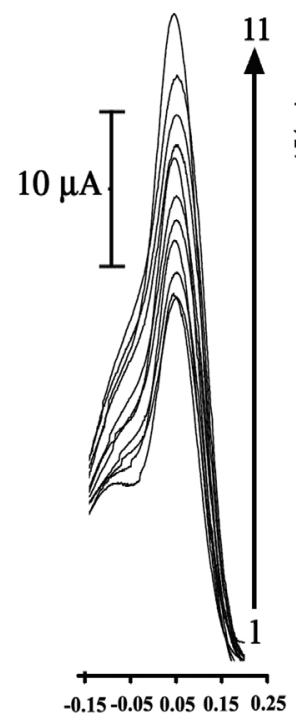

$\mathrm{E} / \mathrm{V}$
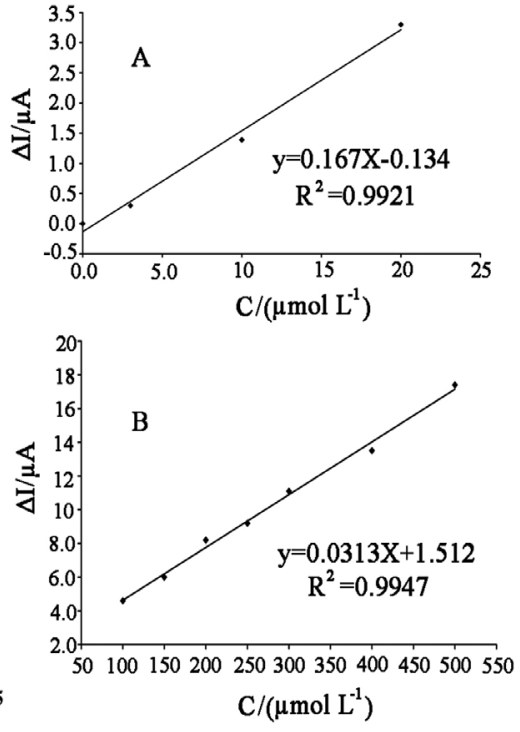

Figure 9. Diffrential pulse voltammograms of levodopa at various concentration: 1) $0.0,2) 3.0,3) 10,4$ ) 20, 5) 100, 6) 150, 7) 200, 8) 250 , 9) 300 , 10) 400 and 11) $500 \mu \mathrm{mol} \mathrm{L}^{-1}$ levodopa at the surface of CAMCPE; Conditions: $\mathrm{pH} \mathrm{10.0;} \mathrm{KCl} 0.1 \mathrm{~mol} \mathrm{~L}^{-1}$; scan rate $10 \mathrm{mV} \mathrm{s}^{-1}$; Insets A) and B) are plots of the electrocatalytic net peaks current $v s$. levodopa concentrations.

\section{Interference study}

In order to evaluate the selectivity of the proposed method for the determination of benserazide and/or levodopa, the influence of various foreign species on the determination of $50.0 \mu \mathrm{mol} \mathrm{L} \mathrm{L}^{-1}$ benserazide and/or levodopa was investigated. The tolerance limit was taken as the maximum concentration of the foreign substances, which caused an approximately $\pm 5 \%$ relative error in the determination. The results presented in Table 2 show that the peak current of benserazide and/or levodopa is not affected by certain conventional cations, anions, and organic substances.

Table 2. Interference study for $50.0 \mu \mathrm{mol} \mathrm{L} \mathrm{L}^{-1}$ benserazide and/or levodopa

\begin{tabular}{lc}
\hline Species & $\begin{array}{c}\text { Tolerante limits } \\
\left(\mathrm{W}_{\text {substance }} / \mathrm{W}_{\text {analyte }}\right)\end{array}$ \\
\hline $\mathrm{HCO}_{3}^{-}, \mathrm{I}^{-}, \mathrm{F}^{-}, \mathrm{NO}_{2}^{-}, \mathrm{ClO}_{4}^{-}, \mathrm{Br}^{-}$ & 1000 \\
Fructose, Glucose, Salycilic acid, Aspirin & 400 \\
Urea, Sucrose & 300 \\
Cysteine & 5 \\
Ascorbic acid, Dopamine & 1 \\
\hline
\end{tabular}

\section{Analytical applications}

In order to check the applicability of the method to real sample analysis, we selected urine samples to analyze for their benserazide and levodopa contents using the standard addition method. The results are given in Table 3. These results demonstrate the capability of CAMCPE in voltammetric determination of benserazide and levodopa in real samples with good recoveries of the spiked benserazide and levodopa and good reproducibility.

Table 3. Determination of benserazide and levodopa in urine sample

\begin{tabular}{lcccc}
\hline Sample & $\begin{array}{c}\text { Added } \\
\left(\mathrm{mmol} \mathrm{L}^{-1}\right)\end{array}$ & $\begin{array}{c}\text { Found } \\
\left(\mathrm{mmol} \mathrm{L}^{-1}, \mathrm{n}=8\right)\end{array}$ & $\begin{array}{c}\text { Recovery } \\
(\%)\end{array}$ & $\begin{array}{c}\text { RSD } \\
(\%)\end{array}$ \\
\hline Benserazide in & & & & \\
Urine 1 & - & $<$ Detection limit & - & - \\
Urine 1 & 0.500 & $0.508 \pm 0.014$ & 101.6 & 3.3 \\
Urine 2 & - & $<$ Detection limit & - & - \\
Urine 2 & 0.100 & $0.102 \pm 0.0025$ & 102.0 & 3.1 \\
Levodopa in & & & & \\
Urine 1 & - & $<$ Detection limit & - & - \\
Urine 1 & 0.500 & $0.505 \pm 0.014$ & 101.0 & 3.0 \\
Urine 2 & - & $<$ Detection limit & - & - \\
Urine 2 & 0.100 & $0.1042 \pm 0.0027$ & 104.2 & 3.1 \\
\hline
\end{tabular}

\section{Conclusions}

This work demonstrates the construction of CAMCPE and its application in benserazide and levodopa determinations. The results show that oxidation of benserazide and levodopa is catalyzed by CA at $\mathrm{pH}$ 10.0, whereas the peak potentials of benserazide and levodopa are shifted by 480 and $230 \mathrm{mV}$, respectively, to less positive potentials at the surface of the CAMCPE. The obtained catalytic peak current using cyclic voltammetry was linearly dependent on the benserazide and levodopa concentrations and the limits of detection for benserazide and levodopa were 0.65 and $0.95 \mu \mathrm{mol} \mathrm{L}{ }^{-1}$, respectively. The current sensitivity, good limit of detection, and high selectivity of the CAMCPE for the detection of benserazide prove its potential sensing applications for the determination of benserazide and levodopa in real samples.

\section{Acknowledgments}

The authors wish to thank the Isfahan University of Technology (IUT) Research Council and Center of Excellence in Sensor (IUT) for supporting this work.

\section{References}

1. Goodman-Hilman, A.; Rall, T.; Nier, A.; Taylor, P.; The Pharmacological Basis of Therapeutics, Mc-Graw Hill: New York, 1996.

2. Reynolds, J. E. F.; The Extra Pharmacopeia, The Pharmaceutical Press: London, 1993. 
3. Hasan, B. A.; Khalaf, K. D.; DeLaGuardia, M.; Talanta 1995, $42,627$.

4. Hu, F. Y.; Lu, G.; He, D. Y.; He, S. H.; Zhang, Z. J.; Chin. J. Anal. Lab. 2004, 23, 18.

5. Teixeira, M. F. S.; Bergamini, M. F.; Marques, C. M. P.; Bocchi, N.; Talanta 2004, 63, 1083.

6. Bergamini, M. F.; Stantos, A. L.; Stradiotto, N. R.; Zanoni, M. V. B.; J. Pharm. Biomed. Anal. 2005, 39, 54.

7. Wu, G.; Chromatographia 2000, 52, 371.

8. Letellier, S.; Garnier, J. P.; Spy, J.; Bousquet, B.; J. Chromatogr. B 1997, 696, 9.

9. Boomsma, F.; van der Hoorn, F. A. J.; Schalekamp, M. A. D. H.; Clin. Chim. Acta 1986, 159, 173.

10. Li, W. L.; Rossi, D. T.; Fountain, S. T.; J. Pharm. Biomed. Anal. 2000, 24, 325.

11. Blanco, M.; Valverde, I.; J. Pharm. Biomed. Anal. 2003, 31, 431.

12. Fanali, S.; Pucci, V.; Sabbioni, C.; Raggi, M. A.; Electrophoresis 2000, 21, 2432.

13. Wang, J.; Zhou, Y.; Liang, J.; He, P. G.; Fang, Y. Z.; Chromatographia 2005, 61, 265.

14. He, W. W.; Zhou, X. W.; Lu, J. Q.; J. Chromatogr. A 2006, 1131, 289.
15. Karpinska, J.; Smyk, J.; Wolyniec, E.; Spectrochim. Acta A 2005, 62, 213.

16. Coello, J.; Maspoch, S.; Villegas, N.; Talanta 2000, 53, 627.

17. Pistonesi, M.; Centurion, M. E.; Band, B. S. F.; Damiani, P. C.; Olivieri, A. C.; J. Pharm. Biomed. Anal. 2004, 36, 541.

18. Raoof, J. B.; Ojani, R.; Zamani, S.; Electroanalysis 2005, 17, 1740 .

19. Galus, Z.; Fundamentals of Electrochemical Analysis, Ellis Horwood: New York, 1976.

20. Beitollahi, H.; Mazloum Ardakani, M.; Ganjipour, B.; Naeimi, H.; Biosens. Bioelectron. 2008, 24, 362.

21. Mirmomtaz, E.; Ensafi, A. A.; Karimi-Maleh, H.; Electroanalysis 2008, 20, 1973.

22. Raoof, J. B.; Ojani, R.; Karimi-Maleh, H.; Electroanalysis 2008, 20, 1259 .

23. Ensafi, A. A.; Karimi-Maleh, H.; J. Braz. Chem. Soc. 2009, 20, 880.

24. User Manual for Software FRA 4.9 (Autolab system), Eco Chemie B.V., The Netherlands, 2007.

25. Maritan, A.; Toigo, F.; Electrochim. Acta 1990, 35, 141.

Received: September 5, 2009

Web Release Date: May 4, 2010 